\title{
Synergies from Mergers and Acquisitions: A Study of Ecobank Ghana Limited and the Trust Bank
}

\author{
Article by Daniel Kwabla- King \\ Management, Texila American University, Ghana \\ E-mail:tdanny60@gmail.com
}

\begin{abstract}
The Social Security and National Insurance Trust (SSNIT) the national Pension Scheme managers in Ghana with significant stake in the Ghanaian banking industry, in the year 2011 made a strategic move to drive bank consolidation in Ghana through the swapping of its shares in The Trust Bank (TTB) for ETI's shares in Ecobank Ghana Limited (EBG). This study was set examine whether synergies were derived from the merger. It also examined whether the objectives set by SSNIT were met and finally determine whether the bank has remained competitive after the merger. The approach used for the study was quantitative technique and case study which concluded that the merger of Ecobank Ghana Limited and TTB achieved the intended results for SSNIT.
\end{abstract}

Keywords: Synergies, Merger, Acquisition, Ecobank Ghana Limited, the Trust Bank, SSNIT, Ghana.

\section{Introduction}

The Social Security and National Insurance Trust (SSNIT) which had shares in most banks with controlling interest in TTB, in line with realigning its investments portfolio to achieve maximum returns, decided to drive bank consolidation through the swapping of its shares in The Trust Bank (TTB) for ETI's shares in Ecobank Ghana Limited (EBG). The objective of the merger was to take advantage of efficiencies and synergies leading to enhanced shareholder value. Making a case for the merger, it was established that the core business of TTB was Commercial and retail banking with their focus on Small and Medium Scale Enterprises (SMEs). EBG also had a core business of Corporate Banking with additional value added services in leasing, corporate finance brokerage and assets management. Out of twenty one banks in Ghana at the time of the merger, EBG's income to employee was ranked first and that of TTB was seventh. Another factor considered was that the banks in question did not belong to any union.

The merger sought to create a bigger bank (the second largest after GCB Bank) with the ability to make bigger deals (increase single obligor limits) It was expected that income from the merged banks would be more than the two banks standing alone. The move was expected to propel the merged entity to grow organically thereby opening new branches and employing many more of the unemployed youth in Ghana.

Studies by Barney, (1988) and Cartwright and Cooper, (1988) examined corporate takeover issues within one-dimensional contexts with one issue at a time. From extant literature, empirical research have not produced a critical and tangible evidence for what establishes a successful takeover (Sirower, 1997).

In mergers and acquisition phenomenon, it is essential to conduct an orderly and full analysis of acquisition process. In previous research by Cannella and Hambrick (1993) and Datta et al, (1992), they enquired about the process involved in takeover such as causes or ideas of acquisition, post- acquisition performance, stock returns or operating performance, shareholders wealth in company acquisitions and the impact of post- acquisition combination.

Jerison and Sitkin, (1986) are of the view that the merging process is the critical part in outlining takeover activities. It is therefore very essential to put one's finger on the primary key issues that motivated the takeover process. It is when this is done that success of post-acquisition performance can be determined. Empirically, it adds new empirical evidence and new dimensions to the literature on the synergistic benefits from the merger and acquisition. Quantitative technique approach was used analyzing data to achieve the 
DOI: $10.21522 /$ TIJMG.2015.03.02.Art014

ISSN: $2520-310 \mathrm{X}$

objectives set. The study assembled comprehensive and verifiable evidence on the subject that was available to researchers.

\section{Objectives}

The main objective of the study is to look at the advantages and disadvantages of synergies from mergers and acquisitions. The specific objectives that the study focused on were:

1. Identify whether the merger brought about synergic benefits.

2. To demonstrate whether the objectives set by SSNIT were met.

3. To establish whether the merged bank remained competitive after the merger.

\section{Review of previous studies}

The term mergers and acquisition is normally used to define the coming together of two or more entities. It is also described a situation where two entities come together to form a new entity. In the view of Sudarsnam, (2003) mergers and acquisition has always been one of the very noticeable strategic tools used to achieve the right business objectives. The main reason why entities do merge or acquire another one is to maximize shareholders wealth. This implies that merger and acquisition will take place only if the value of the combined entity exceeds the value of the individual firms standing alone.

Modigliani and Miller (1958) emphasize that, with perfect capital markets, wealth can neither be created nor destroyed by repackaging a business securities as long as the repackaging leave the firms' total cash flows unaffected. This means that in order for a merger or acquisition to create wealth, the after tax cash flow of the combined entity must exceed the sum of the after tax cash flow of the individual firm prior to the merger. Building on an extensive review of synergies from mergers and acquisitions, is examined on the impact on profitability, efficiency, market power, competition, diversification and concentration.

\section{Synergy}

According to Hitt et al., (2001) synergy is the ability of two or more business or entities to generate greater wealth than what the case would have been if they were working apart or alone. Sherman and Rupert, (2006) in their study on banking post-merger integration affirmed that it takes about four years after merger for the synergies to show. Lasher, (2000) also asserted that synergy is when the performance of the firms together is greater than the sum of their individual performances. Some extra value should always be available in a merger that comes to increase the shareholders wealth of the merged entities. Gaughan, (2002) and Oberg, (2004) were of the view that synergy is the benefits derived from the combined the sum of two entities which is greater than the sum effect from two firms standing on their own. Gaughan, (2002) explained further that synergies does not arise automatically out of mergers and acquisitions. The author explained that synergy can arise through financial synergy, material synergy and operational synergy. The extent of synergies realized may depend on whether mergers and acquisitions is a horizontal integration or combination where mergers and acquisitions involve buying out firms in the same production chain. Synergies can also result from a conglomerate combination by mergers and acquisitions in unrelated areas of business.

\section{Sources of synergy}

Considering the potential advantages and results of synergies, it is not surprising that synergies often work as main motivator in merger and acquisition where the opinions mostly involve the financial gains achieved through efficiency enhancement at different levels in the companies (Zollo \& Sing, 2004). Synergy is the creation of added wealth by sharing resources and acquiring benefits that otherwise would not have been possible to be realized or can only be achieved at a greater cost if not through merger. The concept of synergy can also be achieved through revenue enhancement and cost saving.

Acquiring companies pursues a target company for number of reasons. Key amongst them are:

- Industrial power

- Diversification 
- To eliminate inefficiency

- $\quad$ Take advantage of tax reliefs

- Complementary resources

- Intellectual capital

- High market share

Industry power: This is where one firm takes over another firm to reduce competition. Once there is no competition the surviving firm can assume a monopolistic role thereby increasing prices aimed at increasing profits.

Diversification: In the view of Comment and Jarrel, (1995), firms destroy value when they diversify and value is created when they sell off divisions and become more focused. Diversification is a prime goal because it reduces the investor's risk exposure without necessarily reducing portfolio returns. There is always risk reduction through diversification.

Elimination of Inefficiency: Synergies decreases average cost due to the interactions of demand and supply. Jensen and Ruback, (1983) argue that acquisition can occur because of changing technology or market condition that requires restructuring of a firm. Resources and competences that are not utilized effectively can be better utilized if combined with related firm which results in reducing the average cost of production.

Tax Relief: Synergies in some cases can arise in the case a company that cannot receive tax relief because of its inability to generate enough profit. Such a company is better off combining resources with another firm aimed at generating the required profits thereby making the new firm enjoy the tax reliefs.

Complementary Resources: Synergistic outcomes can be achieved in most cases when the strength of two entities are put together. An example is an entity that has strength in research and development and another that has strength in marketing coming together may lead to great advantages.

Intellectual Capital: Olsson, (1998) used the term intellectual capital as well as the notion of human capital in explaining synergies as covering all knowledge and skills that an individual brings to the workplace. A firm may become a target because of its intellectual capacity. In the banking industry, a bank that desires to enter into Small and Medium Scale sector in an economy will target an existing one with enough knowledge in that sector of banking.

High Market Share: An entity may have a competitive weapon when the industry in which it is operating has a limited product differentiation. In such an environment, the entity will drive prices since it has a larger market share. This can be done by eliminating competition by reducing prices in the short run and then increasing prices later.

Sources of Reverse Synergy

Homburg and Bucerius, (2006) and other researchers have tried to find reasons why mergers or acquisitions have failed. In their view, some of the reasons why synergies might have failed through mergers and acquisitions are:

- Cheap purchases

- $\quad$ Lack of industrial commercial fit

- $\quad$ Lack of goal congruence

Cheap Purchases: Lang et al., (1991) are of the view that firms acquiring other firms for non-value maximizing reasons are characterized by low stock prices relative to their book value and cash flows. Mitchell et al., (1990) also asserted on what they called "bad bidders". This they identified as firms that experience large stock price declines when they announce plans for major acquisitions. The amount of resources in terms of cash and management time could well also damage the acquirer's core business.

Lack of industrial or commercial fit: Failure of synergy can result from a horizontal or vertical takeover where the target firm turns not to have the resources that are estimated by the acquirer. Usually, in cases where it is either horizontal or vertical takeover, the predator has enough information about the targeted entity. Takeovers should be planned carefully and reliance should not be placed on previous experience gained from a direct relationship with the acquired company. 
DOI: $10.21522 /$ TIJMG.2015.03.02.Art014

ISSN: $2520-310 \mathrm{X}$

Lack of Goal Congruence: Where there is no alignment of goals to achieve the overall mission of a firm after a takeover, the gains from the takeover will be eroded by the lack of goal congruence.

\section{Valuation methods in mergers and acquisitions}

A number of valuation methods are available to be used for mergers and acquisitions. Common amongst them is the Capital Assets Pricing model (CAPM). This model is widely used to determine the theoretically appropriate required rate of return for an asset. It is suitable for the pricing of risky assets. There are other valuation methods and they include:

- Net asset valuation

- Price earning based valuation

- Divided valuation Model

- Present value of future cash flow valuation

In all situations, the final price paid would depend on the bargaining skills of the parties as well as the economic pressure on parties involved. It is not in the best interest for the parties to use one valuation methods. Best practice is to use a combination of method ending in getting a fairer consideration for the acquisition.

Net Asset Valuation: This is the type of valuation method that is focused on a company's net assets value (NAV) or fair market value of its assets less its total liabilities to determine what it will cost to recreate that company.

Price Earning Based Valuation: Jensen and Ruback, (1993) emphasize that, on average, target shares increase in price from about 16 to 30 percent around the date of the announcement of a tender offer. These models are based on two elements; the price or earnings (P/E) ratio and the profit tax earnings per share (EPS) of a business, which when combined give the market price per share (MPS). MPS is given as:

Current market price per share

Post tax earnings per share

$\mathrm{MPS}=\mathrm{P} / \mathrm{E}^{*} \mathrm{EP}$

Dividend valuation model: This is the procedure of valuing the price of a stock using the expected dividends and discounting same to their present values. Where the results obtained from the calculation is higher than the current trading value of the shares, the stock is said to be undervalued.

Value of share $=$ Dividend per share

Discount rate-Dividend growth

Present value of future cash flow valuation: Also called the discounted cash flow value, Present value of future stream of cash flows that have been discounted. The higher the rate of discount the lower the present value of future cash flows. This valuation method is used to appraise investment opportunities. Where the value obtained after discounting the cash flows is higher than the current cost of investment, then the opportunity may be a good one.

\section{Financing mergers and acquisitions}

The financing method for mergers and acquisition like any other investment, plays a significant role in whether the investment is feasible. Franks et al., (1989) and Travlos (1987) established that financing method largely affects the success or otherwise of the whole transaction. Mergers and acquisitions can be financed by the methods discussed below.

Cash: Pike et al., (1993) are of the view that everyone understands cash offer since the amount is certain that is there is no exposure to risk adverse movement in share pricing of a bid. Cash is the cheapest of the financing methods in that it is instant and is also "mess free". The only challenge is that the amount of cash required for such transactions are huge and may not be always available. 
Debt: Debt as a method of financing mergers and acquisitions can be expensive as it comes with interest payments and may be repaid over a very long period of time. This can significantly affect transaction cost and should be considered during the process of pricing. However, the good thing about debt is that it is relatively very easy to come by and is much more flexible than cash in terms of debt repayment plans.

Share to Share Exchange: Most of the time, huge merger deals involves share exchange either in part or in full. It is perfectly normal for an IPO to be used to finance a merger deal. Another way is through stock swap. This where shareholders agree to swap their shares for a set of a number of shares of the acquiring entity.

Eckbo et al., (1990) suggested that uncertainty about the target value also turns to lead firms to use stock offer as against cash offer.

\section{Methodology}

The study was focused on assessing synergies from mergers of Ecobank Ghana limited and TTB. Both secondary and primary data was used for the study. Secondary data was specifically obtained from the Valuation Report of the merger and also from the annual reports of Ecobank Ghana Limited. Quantitative technique was applied. In the view of Creswell, (2012) quantitative approach helps to understand the best prediction of outcomes. Case study approach was also adopted because primary data was obtained from key staff of EBG. This is in line with the view of Patton, (1990) who suggested that case study and quantitative approach consists of direct information, written documents and in-depth-open ended interview. Data gathered for this research were analyzed and presented in tables to give them clearer meaning.

\section{Discussion and analysis}

\section{Methods of valuation}

Four methods of valuations were used in determining the value of TTB. These were discounted cash for method, adjusted book value method, $\mathrm{P} / \mathrm{E}$ multiplier valuation and $\mathrm{P} / \mathrm{B}$ multiplier valuation method.

By the DCF approach the estimated market value of TTB was GHC296.44 million. Using the discounted dividend approach, TTB was with GhC138.42 million.

Using the P/E Ratio, TTB's value was GHC255.23 using the adjusted net assets valuation, the bank was value at GHC127.05 million.

From the methods used, the value of TTB ranged from GHC127.05 million to GHC296.44 million.

In coming out with the final value of the bank the results from the various valuation methods was weighted to as in table 1 below:

Table 1. Valuation of TTB

\begin{tabular}{|l|l|l|l|}
\hline \multicolumn{1}{|c|}{ Methodology } & \multicolumn{1}{|c|}{$\begin{array}{c}\text { Valuation } \\
\text { GHC million }\end{array}$} & $\begin{array}{c}\text { Weight } \\
\text { \% }\end{array}$ & \multicolumn{1}{|c|}{$\begin{array}{l}\text { Weight Value } \\
\text { GHC million }\end{array}$} \\
\hline Discounted Cash Flow Method & 296.44 & 15 & 44.47 \\
\hline Adjusted Book value & 127.05 & - & - \\
\hline P/E Multiplier Valuation & 137.61 & 35 & 48.16 \\
\hline P/B Multiplier Valuation & 255.23 & 50 & 127.61 \\
\hline Total Value & & & \\
\hline Number of share (million) & & & $\mathbf{2 2 0 . 2 4}$ \\
\hline Price per share & & & 17.50 \\
\hline
\end{tabular}

Source: Valuation Report of TTB

A fair value of TTB on stand-alone basis was determined to be GHC220.20 million.

\section{Valuation of EBG}

In the valuation of EBG, the same valuation methods were used and the results are in the table 2 below: 
DOI: $10.21522 /$ TIJMG.2015.03.02.Art014

ISSN: $2520-310 \mathrm{X}$

Table 2. Summary of valuation of ecobank ghana limited

\begin{tabular}{|l|l|l|l|}
\hline Methodology & Valuation GHC, million & \multicolumn{1}{|c|}{$\begin{array}{l}\text { Weight Weighted Value } \\
\text { GHC, million }\end{array}$} \\
\hline Discounted Cash Flow & 852.13 & 30 & 255.64 \\
\hline Adjusted Book - Net Assets & 209.08 & 0 & - \\
\hline P/E Multiplier Valuation & 793.95 & 30 & 238.18 \\
\hline Total Value of EBG & & & 816.01 \\
\hline Number of Shares (million) & & & 230.13 \\
\hline & & 3.55 & \\
\hline
\end{tabular}

Source: Valuation Report of TTB

It should be noted that EBG was listed on the Ghana Stock Exchange and at the time of this valuation the market price was GHC, 3.45 per share.

The payment method was share exchange. Table 3 below illustrates the value of the combined banks.

Table 3. Share exchange ratio - controlling interest valuation

\begin{tabular}{|l|l|}
\hline Number of DBG share (million) & 230.13 \\
\hline Number of TTB shares (million) & 17.50 \\
\hline Price per share of EBG (GHC) & 3.45 \\
\hline Price per Share of TTB (GHC) & 16.42 \\
\hline Market Value of EBG (equity before Merger (GHC) $)$ & 93.95 \\
\hline Total Value of TTB (equity before Merger(GHC) & 220.24 \\
\hline $\begin{array}{l}\text { Exchange Ratio (Price of TTB shares/Price of EBG } \\
\text { shares }\end{array}$ & 4.76 \\
\hline Number of shares exchanged (million) & 83.31 \\
\hline Number of share in new entity (million) & 313.44 \\
\hline Total value of equity in new entity (GHC million) & $1,081.35$ \\
\hline Price per share of new entity (GHC) & 3.45 \\
\hline TTB's \% of new entity & $27 \%$ \\
\hline
\end{tabular}

Source: Valuation report of TTB

Discussions will now be led to establish whether the objectives set were met.

Did the new entity benefit from synergies?

It is clear from the study that the new entity benefited from both operational and financial synergies. This is illustrated in table 4 below:

Table 4. Interest on income

\begin{tabular}{|c|c|c|c|c|c|c|c|}
\hline \multicolumn{7}{|c|}{ Interest on Income } & \multirow[b]{2}{*}{2016} \\
\hline & 2010 & 2011 & 2012 & 2013 & 2014 & 2015 & \\
\hline & $\begin{array}{r}\text { GHф } \\
\text { million }\end{array}$ & $\begin{array}{r}\text { GHc } \\
\text { million }\end{array}$ & $\begin{array}{l}\text { GHc } \\
\text { million }\end{array}$ & $\begin{array}{l}\text { GHe } \\
\text { million }\end{array}$ & $\begin{array}{r}\text { GHф } \\
\text { million }\end{array}$ & $\begin{array}{l}\text { GHc } \\
\text { million }\end{array}$ & $\begin{array}{l}\text { GHc } \\
\text { million }\end{array}$ \\
\hline Interest Income & 213.9 & 159.5 & $344 . .3$ & 457.8 & 660.6 & 790.9 & 878.91 \\
\hline \% Increase & - & $(25.4)$ & 60.9 & 114.1 & 208.9 & 269.4 & 11.12 \\
\hline
\end{tabular}

Data Source: EBG Annual Reports 
Information from the Financial Statements of EBG covering the period 2010 to 2016, the new entity's income started increasing from the year 2012 which was a year after the merger.

\section{Was the SSNIT objective of increased investment returns met?}

One key objective of the realignment of SSNIT's investments was to maximize returns from all its investments. Investment returns in a listed bank like EBG is appreciation in share prices and dividends.

Table 5 below shows dividend received from 2010 to 2016.

Table 5. Dividends received

\begin{tabular}{|l|l|l|}
\hline YEAR & $\begin{array}{l}\text { DIVIDEND } \\
\text { RECEIVED(GHC) }\end{array}$ & \%GROWTH \\
\hline 2010 & 390,000 & 0 \\
\hline 2011 & 434,000 & 11.28 \\
\hline 2012 & $11,294,000$ & 2,500 \\
\hline 2013 & $13,768,000$ & 22.01 \\
\hline 2014 & $20,455,000$ & 48.60 \\
\hline 2015 & $37,500,000$ & 83.32 \\
\hline 2016 & $39,879,000$ & 6.34 \\
\hline
\end{tabular}

Source. Financial Statements of SSNIT

Table 5 above demonstrates dividends received from EBG by SSNIT over the period 2010 to 2016. It can be deduced from the table above that SSNIT took the right decision by bringing about the merger. Prior to the merger, TTB had not made any dividend payments to SSNIT in three years and EBG was regular in the payment of dividends but only in thousands of Ghana Cedis. Two years after the merger, EBG started paying dividends in millions of Ghana Cedis.

\section{Has the new entity remained competitive?}

Table 6 below illustrates how the new entity has remained competitive after the merger. Apart from the year of the merger when profit before tax dipped by $(9.31 \%)$, profit after tax remained positive throughout.

Table 6. Profit before income tax

\begin{tabular}{|l|l|l|l|l|l|l|l|}
\hline & $\mathbf{2 0 1 0}$ & $\mathbf{2 0 1 1}$ & $\mathbf{2 0 1 2}$ & $\mathbf{2 0 1 3}$ & $\mathbf{2 0 1 4}$ & $\mathbf{2 0 1 5}$ & $\mathbf{2 0 1 6}$ \\
\hline & $\begin{array}{l}\text { GHф } \\
\text { million }\end{array}$ & $\begin{array}{l}\text { GHф } \\
\text { million }\end{array}$ & $\begin{array}{l}\text { GHф } \\
\text { million }\end{array}$ & $\begin{array}{l}\text { GH } \\
\text { million }\end{array}$ & $\begin{array}{l}\text { GHф } \\
\text { million }\end{array}$ & $\begin{array}{l}\text { GHф } \\
\text { million }\end{array}$ & $\begin{array}{l}\text { GHф } \\
\text { million }\end{array}$ \\
\hline Profit & 113.15 & 102.62 & 196.19 & 261.84 & 433.54 & 457.19 & 461.08 \\
\hline \% Growth & 0 & $(9.31)$ & 91.00 & 33.47 & 65.57 & 5.56 & 0.85 \\
\hline
\end{tabular}

Data Source: EBG annual reports

\section{Summary and conclusion}

The study sought to examine the merger of EBG and TTB achieved the desired results set out by SSNIT. It can be concluded from the analysis that the new entity achieved both operational and financial synergies. Operational synergies include both economies of scale and of scope, improved diversification of revenue sources, increased market share and assets deposits, combination of skill base and consolidation of staff functions to achieve cost reduction. Financial synergies in this context refers to increased equity base, rationalization of procurement, unification of staff function to achieve cost reduction and saving.

From the analysis, conclusions can be drawn that the objectives set by SSNIT were met. This was deduced from increasing profit of the new entity out of which increased dividends were paid. The asset 
DOI: $10.21522 /$ TIJMG.2015.03.02.Art014

ISSN: $2520-310 \mathrm{X}$

base of the bank has also reflected a positive upward movement. Profit after tax also portrayed the same picture.

\section{Recommendation}

Based on the success of the merger of EBG and TTB and its positive effect on the banking landscape of Ghana, this author is recommending that there should be more of such moves in light of the fact that the Central Bank of Ghana is considering an upward movement in the minimum capital of banks in Ghana. Mergers in the banking industry at this time in the history of Ghana is likely to position the banks to undertake big ticket deals in the light of the expansion in the Ghanaian economy due the drilling of oil and gas in commercial quantities.

\section{Reference}

[1]. Cannella, A., and Hambrick, D. C. (1993). Effects of Executive Departures on Performance of Acquired Firms. Strategic Management Journal, 14(S1), pp. 138-152.

[2]. Cartwright, S., \& Cooper, C. L. (1988). The Psychological Impact of Merger and Acquisition on the Individual: A study of building society managers. Human relations, 46(3), pp. 327-347.

[3]. Comment, R., \& Jarrell, G. A. (1995). Corporate Focus and Stock Returns. Journal of Financial Economics, 37(1), pp. 67-87.

[4]. Creswell, J. W. (2012). Educational Research: Planning, Conducting and Evaluating Quantitative and Qualitative Research (4th edition). Upper Saddle River, NJ: Merrill.

[5]. Datta, S., Iskanadar-Datta, M., \& Raman, K. (1992). Executive Compensation and Corporate Acquisition Decisions. The Journal of Finance, 56(6), pp. 2299-2336.

[6]. Diliman, D. A. (2000). Mail and Internet Survey: The tailored Design Method. New York: Wiley.

[7]. Eckbo, B. E., Giammanrino, R. M., \& Heinkel, R. L. (1990). Asymmetric Information and the Medium of Exchange in Takeovers: Theory and Tests. Review of Financial Studies, 3(4), pp.651-675.

[8]. Franks, J. R., \& Harris, R. S. (1989). Shareholder Wealth Effects of Corporate Takeovers: The UK Experience 1955-1985.Journal of Financial Economics, 23(2), pp. 225-249.

[9]. Gaughan, P. A. (2002). Mergers, Acquisitions and Corporate Restructings. New York: John Wiley and Sons Incorporated.

[10]. Hitt, M. A., Harrisson. J. S., \& Ireland, R. D. (2001). Mergers and Acquisitions: A Guide to Creating Value for Stakeholders. Oxford University Press.

[11]. Homburg, C., \& Bucerius, M. (2006). Is Speed of Integration Really a Success Factor of Mergers and Acquisitions? An Analysis of the role of Internal and External Relatedness. Strategic Management Journal, 27(4), pp. 347-367.

[12]. Jensen, M, C., \& Ruback, R. S. (1983). The Market for Corporate Control: The Scientific Evidence. The Journal of Finance Economics, 11, pp. 5-50.

[13]. Jerison, D. B., \& Sitkin, K. (1986). Corporate Acquisitions: A Process Perspective. Academy of Management Review, 11, pp. 145-163

[14]. Lang, L. H. P., Stulz, R. M., \& Walkling, R. A. (1991). A Test of Free Cash Flow Hypothesis: The Case of Bidder Returns. The Journal of Finance Economics, 29, pp. 315-336.

[15]. Lasher, W. R. (2000). Practical Financial Management. 2nd Edition. United States of America. Souther-WesternThomson Learning.

[16]. Mitchell, M. L., \& Lehn, K. (1990). Do Bidders Become Good Targets? Journal of Political Economy, 98, pp. 372-398.

[17]. Modigliani, F., \& Miller, M. H. (1958). The Cost of Capital, Corporation Finance and the Theory of Investment. American Economic Review, 48(3), pp. 261-297.

[18]. Oberg, C. (2004). On Customers in Mergers and Acquisitions. Department of Management and Economics. Linköping, linköping University. 
[19]. Patton, M. Q. (1999). Enhancing the Quality and Credibility of Qualitative Analysis. HSR: Health Service Research, 34(5), pp. 1189-1208.

[20]. Pike, R., \& Neale, B. (1993). Corporate Finance \& Investment Decisions and Strategies. 6th edition, pp. 564.

[21]. Sherman, H. D. \& Rupert, T. J. (2006). Do Bank Mergers have hidden or Forgone Value? Realized and Unrealized Operating Synergies in One Bank Merger. European Journal of Operational Research, 168, pp. 253-268.

[22]. Sirower, M. (1997). The Synergy Trap: How Companies Lose the Acquisition Game: New York: The Free Press. [23]. Sudarsanam, S. (2003). Creating Value from Mergers and Acquisitions. Harlow: Pearson Education Limited.

[24]. Travlos N. G. (1987). Corporate Takeover Bids, Methods of Payment and Bidding Firms' Stock Returns. Journal of Finance, 42, pp. 943-963.

[25]. Zollo, M., \& Singh, H. (2004). Deliberate Learning in Corporate Acquisitions: Post Acquisition Strategies and Integration Capability in U.S. Banker Mergers. Strategic Management Journal, 25, pp. 1233-1256. 